\title{
ANALISIS FAKTOR-FAKTOR YANG MEMPENGARUHI PERMINTAAN SALAK PONDOH DI KOTA LHOKSEUMAWE
}

\author{
Ita Puspita Sari ${ }^{\mathrm{a}^{*}}$, Cut Putri Mellita Sari $\mathrm{a}^{\text {* }}$ \\ ${ }^{a}$ Fakultas Ekonomi dan Bisnis Universitas Malikussaleh \\ *Corresponding author : puspitaita778@gmail.com \\ * cmellita07674@gmail.com
}

\section{A B S T R A C T}

\section{Keywords:}

Salak Pondok Price, Salak Medan Price, Income Level and demand
The purpose of this study is to know the effect of Salak Pondoh Prices, Medan Salak Prices and Income Levels on the Demand for Salak Pondoh in Lhokseumawe City. This study used primary data collecta from 100 respondents. This study utilizes multiple linear regression with the help of Eviews 10. The results of the study showed that Salak Pondok prices had a positive effect on demand, while the Salak Medan prices had a negative effect on demand, and the income levels had an positively effect on demand, but simultaneously, Salak Pondoh prices and Salak Medan prices, and income level had a positive effect on the demand for Salak Pondoh in Lhokseumawe City and the magnitude of the effect of Salak Pondoh prices, Salak Medan Prices and income levels on demand.

\section{PENDAHULUAN}

Perkembangan penduduk Indonesia yang cukup pesat dewasa ini, menyebabkan pemenuhan kebutuhan semakin besar. Perkembangan terlihat pada semakin meningkatnya jenis dan ragam kebutuhan masyarakat termasuk pemenuhan pangan. Kebutuhan pangan manusia tidak terbatas jenis bahan makanan yang dibutuhkan manusia untuk mempertahankan kualitas hidupnya.

Sektor pertanian merupakan salah satu sektor yang sangat penting di Indonesia sebagai salah satu sektor yang dapat menggerakkan dan menambah devisa negara melalui ekspor. Terdapat banyak sub sektor dalam perekonomian pertanian salah satunya sub sektor dari sektor pertanian. Selanjutnya, dalam sub sektor pertanian terdapat sub sektor holtikultural. Sub sektor holtikultural seperti komoditi buah-buahan merupakan salah satu komoditi yang memiliki prospek cukup besar untuk dikembangkan di Indonesia.

Saat ini buah-buahan menjadi salah satu bahan makanan yang telah menjadi kebutuhan bagi masyarakat Indonesia. Hal ini berkembang seiring dengan meningkatnya kesadaran masyarakat untuk memperbaiki kualitas pemenuhan kebutuhan gizinya, yang tentu saja harus didukung kapasitas untuk memenuhi kebutuhan tersebut. Kapasitas inilah yang membedakan kualitas dan kuantitas pemenuhan kebutuhan pangan termasuk buahbuahan pada berbagai kalangan masyarakat Indonesia. Buah-buahan merupakan salah satu komoditas holtikultural yang mengandung vitamin, mineral, dan serat.

Menurut Hanafiah dan Saefuddin (2015)

buah salak memiliki beberapa keuanggulan, antara lain memiliki kandungan gizi yang cukup lengakp, sumber serat yang baik, mengandung karbohidrat yang cukup tinggi, dapat menurunkan kolesterol dalam tubuh, menurunkan kadar gula dalam darah, mempertahankan kelembaban kulit, mempertahankan struktur tulang, dan meningkatkan daya tahan tubuh terhadap serangan penyakit (antibodi).

Khusus di Kota Lhokseumawe, buah salak dapat diperoleh di pasar tradisional dan modern. Rumah tangga sebagai konsumen pada umumnya 
lebih dominan berbelanja di pasar tradisional karena harga produk lebih terjangkau. Adapun jenis salak yang tersedia adalah berbagai salak pondok yang manis dan memiliki khasiat dengan harga lebih terjangkau, memiliki rasa yang khas.

Permintaan konsumen rumah tangga akan komoditi dalam hal ini salak adalah banyaknya komoditi salak yang dibutuhkan dan dibeli oleh konsumen, merupakan contoh dari permintaan konsumen. Besar kecilnya komoditi salak umumnya dipengaruhi oleh harga, harga harga buah lain atau harga komplemennya, selera dan keinginan, jumlah konsumen dan pendapatan konsumen yang bersangkutan. Sedangkan permintaan pedagang pengecer dalam hal ini salak merupakan permintaan turunan (Hanafiah dan Saefuddin, 2015).

Berdasarkan observasi awal diperoleh dari responden yang menjadi lokasi di penelitian ini sebagai berikut:

\section{Tabel 1}

\section{Observasi Awal}

\begin{tabular}{|c|c|c|c|c|}
\hline $\begin{array}{c}\mathrm{N} \\
\mathrm{o}\end{array}$ & $\begin{array}{c}\text { Permint } \\
\text { aan } \\
(\mathrm{Kg})\end{array}$ & $\begin{array}{c}\text { Harga } \\
\text { salak } \\
\text { pondok } \\
(\mathrm{Rp} / \mathrm{kg})\end{array}$ & $\begin{array}{c}\text { Harga } \\
\text { salak } \\
\text { medan } \\
(\mathrm{Rp} / \mathrm{kg})\end{array}$ & $\begin{array}{c}\text { Tingkat } \\
\text { pendapatan } \\
(\mathrm{Rp})\end{array}$ \\
\hline 1 & 3 & 10.000 & 8.000 & 2.500 .000 \\
\hline 2 & 2 & 12.000 & 10.000 & 2.700 .000 \\
\hline 3 & 5 & 11.000 & 8.000 & 1.500 .000 \\
\hline 4 & 2 & 15.000 & 20.000 & 4.000 .000 \\
\hline 5 & 4 & 17.000 & 18.000 & 2.700 .000 \\
\hline
\end{tabular}

\section{Sumber : Observasi awal}

Berdasarkan hasil observasi awal pada tabel 1 di atas dapat dijelaskan bahwa berbedabeda variabel harga barang yang bersangkutan, harga barang lain, dan tingkat pendapatan yang akan mempengaruhi permintaan Salak Podok di Pasar Buah Kota Lhokseumawe.

DarihasilIbnu(2016) dalam penelitian analisis faktor-faktor yang mempengaruhi permintaan semangka di Kecamatan Baki Kabupaten Sukoharjo. Hasil penelitian menunjukkan bahwa faktor-faktor yang terdiri dari harga semangka, harga apel, harga pepaya, harga pisang, jumlah keluarga, dan pendapatan rumah tangga konsumen secara bersama-sama berpengaruhnya taterhadap jumlah permintaan semangka di Kecamatan Baki. Secara individu, faktor-faktor yang mempengaruhi tersebut juga memepengaruhi permintaan semangka di Kecamatan Baki kecuali harga papaya. Permintaan semangka bersifat inelastis karena nilai elastisitasnya lebih kecil dari satu yaitu sebesar0,399 . Buah apel terhadap semangka bersifat komplementer karena elastisitas silangnya bernilai negative yaitu sebesar-0,249. Buah pisang terhadap semangka bersifat komplementer karena elastisitas silangnya bernilai negatif yaitu sebesar0,463 . Buah semangka bersifat barang normal karena nilai elastisitas pendapatan lebih besar dari 0 dan bernilai positif0, 318. Berdasarkan hasil penelitian dapat disarankan sebaiknya petani semangka lebih cermat dalam merencanakan penanaman semangka. Jumlah yang ditanam sebaiknya disesuaikan dengan permintaan disaat waktu panen. Selainitu, saran bagi pedagang sebaiknya lebih meningkatkan promosi untuk meningkatkan penjualan buah.

Tujuan dari penelitian ini adalah untuk menguji pengaruh harga salak pondok, harga salak medan dan Menguji pengaruh tingkat pendapatan berpengaruh terhadap permintaan Salak Pondok di Pasar Buah Kota Lhokseumawe.

Selanjutnya pembahasan dibagian kedua dalam artikel ini adalah tinjauan teoritis, dibagian ketiga dibahas tentang metode penelitian. Pada bagian keempat membahas hasil dan pembahasan dan akhirnya kesimpulan dan saran pada bagian kelima.

\section{TINJAUAN TEORITIS \\ Permintaan}

Menurut (Soekartawi, 2013) pengertian permintaan dipergunakan untuk mengetahui hubungan jumlah barang yang dibeli oleh konsumen dengan harga alternatif untuk membeli barang yang bersangkutan dengan anggapan bahwa barang lain tetap cateris paribus. Sedangkan menurut (Winardi, 2014) bahwa permintaan akan suatu barang adalah jumlah barang yang sanggup dibeli oleh para pembeli pada tempat dan waktu tertentu dengan harga yang berlaku pada saat itu.

Permintaan suatu komoditi pertanian adalah banyaknya permintaan komoditi pertanian yang dibutuhkan dan dibeli oleh konsumen. Karena itu besar kecilnya komoditi pertanian umumnya 
dipengaruhi oleh harga komplemennya, selera dan keinginan, jumlah konsumen dan pendapatan konsumen yang bersangkutan (Soekartawi, 2013).

Menurut (Saksono, 2002) Permintaaan adalah sejumlah barang dan jasa yang diinginkan untuk dibeli atau dimiliki pada berbagai tingkat harga yang berlaku di pasar pada waktu tertentu. Sedangkan menurut (R.A, 2005) Permintaan adalah jumlah yang akan dibeli per unit waktu menjadi semakin besar apabila harga semakin rendah, keadaan lain tetap sama. hukum permintaan ini berlaku dalam keadaan cateris paribus, artinya apabila faktor-faktor lain berada diluarnya yang mempengaruhi permintaan tidak berubah

\section{Harga yang Bersangkutan}

Harga adalah suatu nilai yang harus dikeluarkan oleh pembeli untuk mendapatkan barang atau jasa yang memiliki nilai guna beserta pelayanannya. Hubungan harga degan permintaan adalah hubungan yang negatif. Artinya apabila yang satu naik maka yang lainnya akan turun dan begitu juga sebaliknya. Semua ini berlaku dengan catatan faktor lain yang mempengaruhi jumlah permintaan dianggap tetap.

Philip Kotler mengungkapkan bahwa harga adalah salah satu unsur bauran pemasaran yang menghasilkan pendapatan, unsur-unsur lainnya menghasilkan biaya. Harga adalah unsur bauran pemasaran yang paling mudah disesuaikan, ciriciri produk, saluran, bahkan promosi membutuhkan lebih banyak waktu.

Harga juga mengkomunikasikan posisi nilai yang dimaksudkan perusahaan tersebut kepada pasar tentang produk dan mereknya (Sukirno, 2012). Harga bagi suatu usaha atau badan usaha menghasilkan pendapatan (income), adapun adapun unsur-unsur bauran pemasaran lainnya yaitu Product (produk), Place (tempat/sal uran) dan Promotion (promosi) menimbulkan biaya atau beban yang harus ditanggung oleh suatu usaha atau badan usaha.

Berdasarkan para pakar diatas makan dapat diambil kesimpulan harga barang bersangkutan adalah total biaya yang dikeluarkan atau dibayar oleh konsumen untuk memperoleh sesuatu barang yang ingin dibeli oleh masyarakat tersebut.
Hubungan harga barang bersangkutan memiliki hubungan positif yang dengan permintaan yang artinya apabila Harga bersangkutan meningkat maka akan meningkat permintaan, disini masyarakat tidak akan mempermasalahkan harga karena apa yang diperlukan itu kebutuhan yang harus dipenuhi.

\section{Harga Barang Lain}

Terjadinya perubahan harga pada suatu barang akan berpengaruh pada permintaan barang lain. Harga barang lain dapat meliputi harga barang subtitusi, komplemen, dan independen. Salah satu contoh barang subtitusi bila harga salak medan naik, biasanya permintaan salak pondoh akan naik. Barang komplementer contohnya salak medan. Apabila keduanya dipakai secara bersamaan sehingga dengan demikian bila salah satu dari harga barang tersebut naik, pada umumnya akan mempengaruhi banyaknya konsumsi barang komplemennya. Barang independen adalah barang yang tidak dipengaruhi oleh harga barang yang lain.

Hubungan antara suatu barang dengan berbagai jenis-jenis barang lainnya dapat dibedakan kepada tiga golongan, yaitu:Barang lain itu merupakan pengganti, Barang lain itu merupakan pelengkapKedua barang tidak mempunyai kaitan sama sekali (barang netral).

Sesuatu barang dinamakan barang pengganti kepada barang lain apabila ia dapat menggantikan fungsi barang lain tersebut. Sekiranya harga barang pengganti bertambah murah maka barang yang digantikannya akan mengalami pengurangan dalam permintaan dan sebaliknya. Apabila sesuatu barang selalu digunakan bersama dengan barang lainnya, maka barang tersebut dinamakan barang pelengkap kepada barang lain tersebut.

Kenaikan atau penurunan permintaan terhadap barang pelengkap selalu sejalan dengan perubahan permintaan barang yang digenapinya. Apabila dua macam barang tidak mempunyai hubungan yang rapat maka perubahan terhadap permintaan salah satu barang tersebut tidak akan mempengaruhi permintaan barang lainnya. Barang seperti ini dinamakan barang netral (Sukirno, 2002). 
Berdasarkan para pakar diatas harga barang lain adalah total harga yang akan dikeluarkan oleh masyarakat untuk membeli sesuatu barang namun terlebih dahulu dibandingkan dengan harga yang akan dibeli sebelumnya.

Hubungan harga barang lain memiliki hubungan negative terhadap permintaan yang apabila harga barang lain meningkat maka akan menurunkan permintaan yang artinya apabila harga barang lain meningkat maka masyarakat akan mencari pengganti barang lain yang dianggap murah, karena barang lain merupakan barang subtitusi oleh masyarakat yang bukan merupakan barang pokok.

\section{Tingkat Pendapatan}

Pendapatan Keluarga adalah seluruh penerimaan baik berupa uang maupun berupa barang yang berasal dari pihak lain maupun hasil industri yang dinilai atas dasar sejumlah uang dari harta yang berlaku saat itu. Pendapatan keluarga merupakan sumber penghasilan seseorang untuk memenuhi kebutuhan sehari - hari dan sangat penting artinya bagi kelangsungan hidup dan penghidupan seseorang secara langsung mau pun tidak langsung (Suroto, 2000).

Pendapatan keluarga merupakan suatu unsur yang harus dilakukan dalam melakukan suatu usaha karena dalam melakukan suatu usaha tentu ingin mengetahui nilai atau jumlah pendapatan yang diperoleh selama melakukan usaha. Pendapatan keluarga merupakan jumlah barang dan jasa yang memenuhi tingkat hidup masyarakat, dimana dengan adanya pendapatan yang dimiliki oleh setiap jiwa disebut dengan pendapatan perkapita dimana pendapatan perkapita menjadi tolak ukur kemajuan atau perkembangan ekonomi.

Pendapatan merupakan factor yang sangat penting dalam menentukan permintaan terhadap berbagai barang. Perubahan pendapatan selalu menimbulkan perubahan terhadap permintaan berbagai jenis barang. Seperti permintaan salak pondoh di pasar buah, harga salak medan lebih murah daripada salak pondoh tetapi konsumen memilih salak pondoh, karena konsumen beranggapan salak pondoh lebih berkualitas rasanya.
Berdasarkan pengertian dari pakar diatas, maka dapat diambil kesimpulan bahwa pendapatan adalah penghasilan yang diterima oleh keluarga untuk memenuhi kebutuhan sehari-hari untuk proses kelangsungan hidup.

Hubungan pendapatan berpengaruh positif terhadap permintaan yang artinya apabila pendapatan meningkat maka akan meningkatkan permintaan, dikarenakan apabila seseorang memiliki pendapatan yang tinggi masyarakat akan meningkatkank onsumsinya dengan melakukan peningkatan pada permintaan.

\section{Karangka Konseptual}

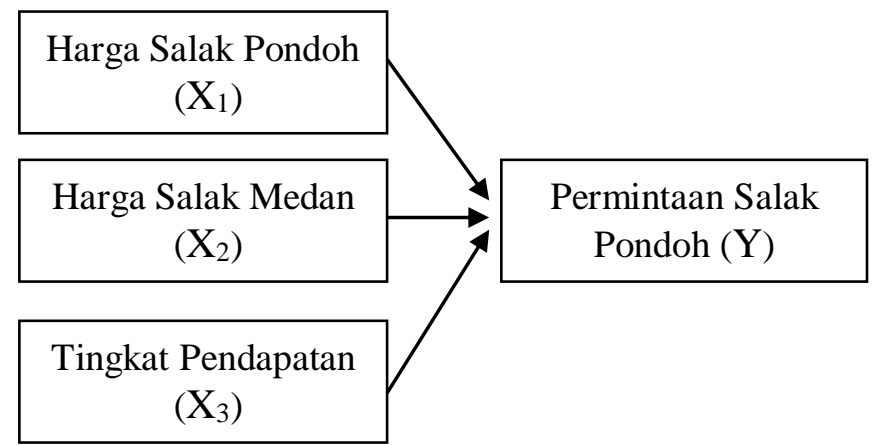

\section{Gambar 1}

\section{Kerangka Konseptual}

Dari gambar 1 di atas penelitian ini akan mengkaji pengaruh harga salak pondoh terhadap permintaan salak pondoh. Demikian juga harga salak medan dan tingkat pendapatan akan diteliti pengaruhnya terhadap permintaan salak pondoh.

\section{Hipotesis}

Berdasarkan kerangka konseptual yang dikemukakan di atas, maka dapat dirumuskan hipotesis alternatif sebagai berikut :

$H_{1}$ : Harga salak pondoh berpengaruh negatif dan siqnifikan terhadap permintaan Salak Pondoh di Pasar Buah Kota Lhokseumawe

$\mathrm{H}_{2}$ : Harga salak medan berpengaruh positif dan siqnifikan terhadap permintaan Salak Pondoh di Pasar Buah Kota Lhokseumawe

$H_{3}$ : Tingkat pendapatan berpengaruh positif dan siqnifikan terhadap permintaan Salak Pondoh di Pasar Buah Kota Lhokseumawe 


\section{METODE PENELITIAN}

\section{Opulasi dan Sampel}

Populasi dalam penelitian ini adalah seluruh petani yang berpropesi sebagai petani karet di Desa Bukit Hagu Kecamatan Lhoksukon Kabupaten Aceh Utara yang berjumlah 147 orang.

Pengambilan sampel dilakukan dengan cara acak sederhana (Simple randomsampling) sehingga diperoleh sampel yang dapat mewakili (Representatif). Dalam penelitian ini tehnik penganbilan sampel yang digunakan adalah menurut rumus Slovin.

$$
n=\frac{N}{1+N e^{2}}
$$

Dimana :

$$
\begin{array}{ll}
\mathrm{N} & =\text { Populasi } \\
\mathrm{n} & =\text { Sampel } \\
\mathrm{e}^{2} & =\text { Persentase } \\
1 & =\text { Konstanta }
\end{array}
$$

Dengan jumlah populasi sebesar 187. 455 masyarakat sebesar 0,10 (10\%), maka jumlah sampel adalah :

$n=\frac{187.455}{1+187.455(0,10)^{2}}$

= 99,94 (dibulatkan menjadi 100)

Dengan demikian jumlah sampel yang diambil dalam penelitian ini adalah sebanyak 100 responden

\section{Definisi Operasional Variabel}

Harga salak pondok (X1): Harga barang yang bersangkutan adalah suatu nilai yang harus dikeluarkan oleh pembeli untuk mendapatkan barang atau jasa yang memiliki nilai guna beserta pelayanannya sesuai dengan barang yang dibelinya. Diukur dengan satuan rupiah.

Harga salak medan (X2): Harga barang lain adalah suatu nilai yang dikeluarkan oleh pembeli untuk mendapatkan barang atau jasa yang memiliki nilai guna beserta pelayanannya sesuai dengan barang yang dibelinya yang dibedakan dengan harga yang ingin dibelli sebenarnya. Diukur dengan satuan rupiah.

Tingkat Pendapatan (X3) : Pendapatan adalah jumlah uang yang diterima oleh rumah tangga selama kurun waktu tertentu (biasanya satu tahun), pendapatan terdiri dari upah atau penerimaan tenaga kerja, pendapatan dari kekayaan seperti sewa, bunga dan dividen, serta pembayaran transfer atau penerimaan dari pemerintah seperti tunjangan sosial atau asuransi pengangguran. Diukur dengan satuan rupiah.

Permintaan (y) : permintaan akan suatu barang adalah jumlah barang yang sanggup dibeli oleh para pembeli pada tempat dan waktu tertentu dengan harga yang berlaku pada saat itu. Diukur dengan satuan rupiah.

\section{Metode Analisis Data}

Metode analisis data yang digunakan dalam penelitian ini adalah metode kuantitatif yaitu dalam pengambilan data secara statistik untuk mempermudah perhitungannya dengan menggunakan data-data statistik. Untuk mengukur pengaruh Harga salak pondok, harga salak medan dan tingkat pendapatan terhadap permintaan salak pondok di pasar buah kota Lhokseumawe digunakan model regresi linier berganda dengan bantuan program EVIEWS Version 10. Adapun formulasi model regresi linier berganda dalam penelitian ini adalah sebagai berikut :

$$
\log Y=\beta_{0}+\beta_{1 \log } X_{1}+\beta_{2 \log } X_{2}+\beta_{3 \log } X_{3}+e
$$

Dimana :

$$
\begin{aligned}
& \mathrm{Y}=\text { Permintaan } \\
& \log \beta_{0} \quad=\text { Konstanta } \\
& \beta_{1} \beta_{2} \beta_{3} \quad=\text { Koefisien regresi variabel } \\
& \log \mathrm{X}_{1} \quad=\text { Harga salak Pondok } \\
& \log \mathrm{X}_{2} \quad=\text { Harga Salak Medan } \\
& \log _{3} \quad=\text { Tingkat pendapatan } \\
& \mathrm{e}=\text { Error term }
\end{aligned}
$$

\section{Uji Normalitas}

Uji normalitas dapat dideteksi dengan membandingkan nilai Jarque-Bera dengan $\mathrm{X}^{2}$ tabel, yaitu :

1. Jika nilai JB $>X^{2}$ tabel, maka residualnya berdistribusi tidak normal.

2. Jika nilai JB $<X^{2}$ tabel, maka residualnya berdistribusi normal. 


\section{Uji Asumsi Klasik}

Sebelum melakukan pengujian hipotesis dengan menggunakan analisis regresi linier berganda perlu dilakukan terlebih dahulu pengujian asumsi klasik, uji asumsi klasik meliputi :

\section{Uji Multikolinieritas}

Menurut (Ghozali, 2012) uji multikolinieritas bertujuan untuk menguji apakah model regresi ditemukan adanya korelasi antar variabel bebas (independen). Model regresi yang baik seharusnya tidak terjadi korelasi diantara variabel bebas. Untuk mendeteksi ada atau tidak multikolinieritas didalam model regresi dapat dilakukan dengan cara menganalisis matrik korelasi variabel-variabel bebas (independen). Jika antar variabel bebas ada korelasi yang cukup tinggi (umumnya diatas 0,80) maka hal ini merupakan indikasi adanya multikolinieritas.

\section{Uji Heteroskedastisitas}

Uji heteroskedastisitas dapat dilihat menggunakan uji white, untuk mendeteksi ada tidaknya heteroskedastisitas atau tidak maka dapat dilihat dengan membandingkan nilai $R$-squared dan $\mathrm{X}^{2}$ tabel.

1. Jika nilai $R$-squared $>X^{2}$ tabel, maka residualnya terkena heteroskedastisitas.

Jika nilai $R$-squared $<\mathrm{X}^{2}$ tabel, maka residualnya terbebas dari heteroskedastisitas.

\section{Pengujian Hipotesis}

\section{Uji Secara Parsial (Uji t)}

Uji t dilakukan untuk melihat signifikansi dari pengaruh variabel bebas secara individual terhadap variabel terhadap variabel terikat dengan menganggap variabel bebas lainnya adalah konstan (Gujarati, 2004). Adapun kriteria pengujiannya adalah sebagai berikut:

1. Jika > Ho ditolak dan menerima Ha yang artinya variabel bebas (X) secara parsial mempengaruhi variabel terikat $(\mathrm{Y})$.

2. Jika < maka Ho diterima dan menolak Ha yang artinya variabel bebas (X) secara parsial tidak mempengaruhi vaiabel terikat (Y).

\section{Uji Secara Serentak (Uji F)}

Uji $\mathrm{F}$ dilakukan untuk mengetahui apakah variabel independen secara keseluruhan signifikan secara statistic dalam mepengaruhi variabel dependen. Apabila uji F hitung lebih besar dari nilai $F$ tabel maka variabel independen secara keseluruhan berpengaruh terhadap variabel dependen (Gujarati, 2004). Adapun kriteria pengujian yang digunakan sebagai berikut:

Jika > maka Ho ditolak dan menerima Ha yang artinya variabel bebas (X) secara simultan atau serentak berpengaruh signifikan variabel terikat $(\mathrm{Y})$

Jika $<$ maka Ho diterima dan menolak Ha yang artinya variabel bebas (X) secara simultan atau serentak tidak berpengaruh signifikan variabel terikat $(\mathrm{Y})$.

\section{Koefisien Korelasi (R)}

Menurut Sugiyono (2013) Koefisien korelasi (R) merupakan akar dari koefisien determinasi. Besarnya hubungan antara variabel yang satu dengan variabel yang lain dinyatakan dengan koefisien korelasi yang disimbulkan dengan huruf " $r$ ". dalam statistic korelasi diberi pengertian sebagai hubungan antara dua variabel atau lebih. Hubungan dua variabel dikenal dengan istilah bivariate correlation, sedangkan hubungan antar lebih dari dua variabel disebut multivariate correlation. Koefisien korelasi adalah sebuah angka yang dapat dijadikan petunjuk untuk mengetahui seberapa besar kekuatan korelasi di antara variabel yang sedang diselidiki korelasinya.

Alat analisis koefisien korelasi yang digunakan yaitu metode pearson atau product moment. Nilai korelasi (R) berkisar antara 1 sampai -1 , nilai semakin mendekati 1 atau -1 berarti hubungan antara dua variabel semakin kuat, sebaliknya nilai mendekati 0 berarti hubungan antara dua variabel semakin lemah. Milai positif menunjukkan hubungan searah (X naik maka $\mathrm{Y}$ naik) dan nilai negatif menunjukkan hubungan terbalik ( $\mathrm{X}$ naik maka $\mathrm{Y}$ turun). Pedoman untuk memberikan interpretasi koefisien sebagai berikut:

$>0,00-0,199=$ sangat rendah

$>0,20-0,399=$ rendah 
$>0,40-0,599=$ sedang

$>0,60-0,799=$ kuat

$>0,80-0,99=$ sangat kuat

$>1=$ korelasi sempurna

\section{Koefisien Determinasi (R2)}

Koefisien determinasi (R2) adalah satu ukuran yang digunakan untuk mengukur pengaruh variabel independen terhadap variansi dependen, dengan $0<1$. Koefisien determinasi pada regresi linier sering diartikan sebagai seberapa besar kemampuan semua variabel bebas dalam menjelaskan varians dari variabel terikatnya. Secara sederhana koefisien determinasi dihitung dengan mengkuadratkan Koefisien Korelasi (R). dalam statistic, koefisien determinasi (R), digunakan dalam konteks model statistik yang tujuan utamanya adalah prediksi hasil masa depan berdasarkan informasi terkait lainnya. Ini adalah proporsi variabilitas dalam suatu kumpulan data yang dicatat dengan model statistik. Ini memberikan ukuran seberapa baik hasil masa depan mungkin akan diprediksi oleh model (Ghozali, 2010).

\section{HASIL PENELITIAN DAN PEMBAHASAN}

\section{Asumsi Klasik}

\section{Uji Normalitas}

Untuk melihat kenormalan data pada penelitian ini dapat dilihatpada gambar di bawah ini :

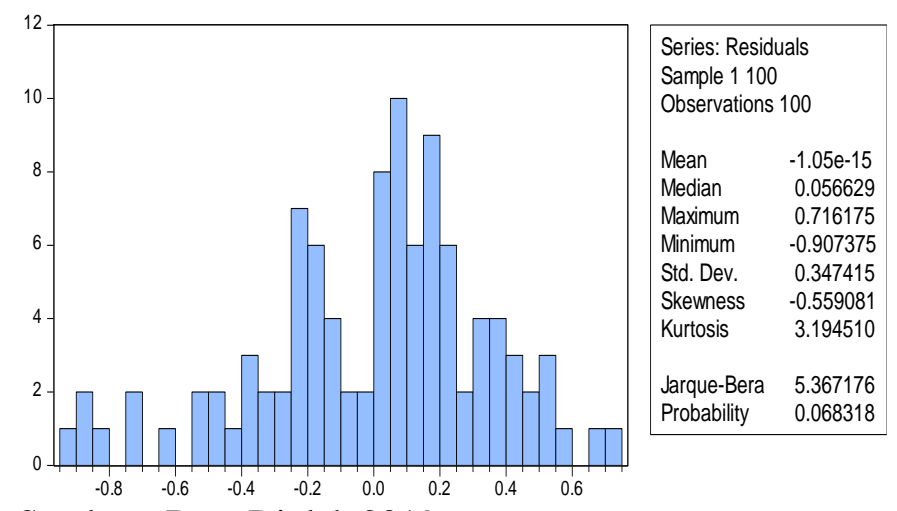

Sumber : Data Diolah 2019

\section{Gambar 2}

Hasil Uji Normalitas
Hasil dari uji normalitas pada gambar di atas bahwa nilai JB $(5,36)<X^{2}$ tabel $(7,81)$ maka dapat disimpulkan bahwa residual berdistribusi normal.

\section{Uji Multikolinieritas}

Untuk melihat ada tidaknya indikasi terjadinya multikolinieritas pada penelitian ini dapat dilihat pada tabel di bawah ini :

Tabel 2

\section{Hasil Uji Multikolinieritas}

\begin{tabular}{|l|c|c|c|}
\hline & $\begin{array}{c}\text { Log(Harga } \\
\text { Salak } \\
\text { Pondok) }\end{array}$ & $\begin{array}{c}\text { Log(Harga } \\
\text { Salak } \\
\text { Medan) }\end{array}$ & $\begin{array}{c}\text { Log (Tingkat } \\
\text { Pendapatan) }\end{array}$ \\
\hline $\begin{array}{l}\text { Log(Harga } \\
\text { Salak } \\
\text { Pondok) }\end{array}$ & 1 & 0.210978 & 0.050709 \\
\hline $\begin{array}{l}\text { Log(Harga } \\
\text { Salak Medan) }\end{array}$ & 0.210978 & 1 & 0.140470 \\
\hline $\begin{array}{l}\text { Log(Tingkat } \\
\text { Pendapatan) }\end{array}$ & 0.050709 & 0.140470 & 1 \\
\hline
\end{tabular}

Sumber : Data Diolah 2019

Berdasarkan tabel 2 di atas dapat dilihat bahwa tidak terjadi korelasi yang cukup tinggi antar variabel bebas dan terbebas dari multikolinieritas, hal ini dapat dilihat dari nilai korelasi. Jika nilai korelasi antar variabel bebas di bawah 0,80 maka dapat dikatakan dalam model terbebas dari multikolinieritas.

\section{Uji Heteroskedastisitas}

Untuk melihat ada tidaknya indikasi terjadinya heteroskedastisitas pada penelitian dapat dilihat pada tabel di bawah ini :

Tabel 3

Hasil Uji Heteroskedastisitas

\begin{tabular}{|l|l|l|r|}
\hline \multicolumn{3}{|l|}{ Heteroskedasticity Test: White } & \\
\hline F-statistic & 0.119866 & Prob. F(3,96) & 0.9482 \\
\hline Obs*R-squared & 0.373182 & Prob. Chi-Square(3) & 0.9457 \\
\hline Scaled explained SS & 0.377373 & Prob. Chi-Square(3) & 0.9449 \\
\hline
\end{tabular}

Sumber : Data Diolah 2019

Berdasarkan Tabel 3 di atas menunjukkan bahwa data model yang digunakan dalam penelitian ini terbebas dari heteroskedastisitas, dari hasil tersebut dilihat dari $o b s * R$-Squared $<$ tabel pada $\operatorname{df}(3)=7,81$, sehingga $0,11<7,81$. Hal 
ini juga bisa dilihat dari nilai probability (P-value) sebesar $0,94>0,05$.

\section{Metode Analisis Data}

Dalam penelitian ini peneliti menggunakan analisis regresi linier berganda yang diolah dengan EVIEWS maka didapatkan hasil regresi sebagai berikut :

\section{Tabel 4}

\section{Hasil Output Regresi}

Dependent Variable: PERMINTAAN

\begin{tabular}{lrlrl}
\hline \hline \multicolumn{1}{c}{ Variable } & Coefficient & Std. Error & t-Statistic & Prob. \\
\hline \hline $\begin{array}{c}\text { C } \\
\text { Log (Harga Salak } \\
\text { Pondok) }\end{array}$ & -5.461849 & 2.064766 & -2.645264 & 0.0095 \\
& 1.182654 & 0.152080 & 7.776548 & 0.0000 \\
Log (Harga Salak & & & & \\
$\quad$ Medan) & -0.476958 & 0.139992 & -3.407031 & 0.0010 \\
& & & 7.662729 & 0.0000 \\
Log (Pendapatan) & 0.628783 & 0.082057 & 1839515. \\
\hline \hline R-squared & 0.548144 & Mean dependent var \\
Adjusted R-squared & 0.534023 & S.D. dependent var & 494320.0 \\
S.E. of regression & 305495.2 & Akaike info criterion & 28.16160 \\
Sum squared resid & $5.23 E+12$ & Schwarz criterion & 28.30122 \\
Log likelihood & -840.8479 & Hannan-Quinn criter. & 28.21621 \\
F-statistic & 38.81902 & Durbin-Watson stat & 1.882013 \\
Prob(F-statistic) & 0.000000 & & \\
\hline \hline
\end{tabular}

Sumber : Data Diolah 2019

Dari tabel 4 di atas hasil perhitungan statistik memalui program Eviews maka diperoleh persamaan hasil regresi sebagai berikut :

$\log \mathrm{Y}=-5.461849+1.182654 \operatorname{LnX} 10.476958 \ln \times 2$ $+0.628783 \operatorname{LnX} 3+\mathrm{ei}$

Nilai konstanta sebesar -5.461849 artinya jika variabel harga salak pondok, harga salak medan dan tingkat pendapatan dianggap konstan, maka variabel permintaan juga akan konstan sebesar 5.461849 .

Nilai koefisien regresi harga salak pondok sebesar 1.182654 menunjukkan hubungan positif yang memberi arti jika variabel harga salak pondok meningkat sebesar $1 \%$ maka akan meningkatkan variabel permintaan sebesar $1.182654 \%$ dengan asumsi bahwa variabel harga salak medan dan tingkat pendapatan dianggap tetap.
Nilai koefisien harga salak medan sebesar 0.476958 menunjukkan hubungan negatif yang memberi arti bahwa jika variabel harga salak medan meningkat sebesar $1 \%$ maka akan menurunkan variabel permintaan sebesar $0.476958 \%$ buah dengan asumsi bahwa variabel harga salak pondok dan tingkat pendapatan dianggap tetap.

Nilai koefisien tingkat pendapatan sebesar 0.628783menunjukkan hubungan positif yang memberi arti bahwa jika variabel tingkat pendapatan meningkat sebesar $1 \%$ maka akan meningkatkan variabel permintaan sebesar $0.628783 \%$ buah dengan dengan asumsi variabel harga salak pondok dan harag salak medan dianggap tetap.

\section{Pembuktian Hipotesis \\ Pembuktian Secara Parsial (Uji t)}

Uji t dilakukan untuk melihat signifikansi dari pengaruh variabel bebas secara individual (satu-satu) terhadap variabel terikat dengan menganggap variabel bebas lainnya adalah konstan. Hasil pengujian secara parsial (uji t) dapat dilihat pada tabel di bawah ini :

Tabel 5

Hasil Uji t

\begin{tabular}{|l|c|c|c|c|c|}
\hline \multicolumn{7}{|c|}{ Variabel Dependen (Permintaan) } \\
\hline $\begin{array}{c}\text { Nama } \\
\text { Variabel }\end{array}$ & $\begin{array}{c}\text { t- } \\
\text { statistik }\end{array}$ & t-tabel & Prob & Keterangan & Hipotesis \\
\hline $\begin{array}{l}\text { Harga } \\
\text { Salak } \\
\text { Pondok }\end{array}$ & 7.77654 & 2,62 & 0,0000 & Signifikan & Diterima \\
\hline $\begin{array}{l}\text { Harga } \\
\text { Salak } \\
\text { Medan }\end{array}$ & -3.40703 & 2,62 & 0,0010 & Signifikan & Diterima \\
\hline $\begin{array}{l}\text { Tingkat } \\
\text { Pendapatan }\end{array}$ & 7.66272 & 2,62 & 0,0000 & Signifikan & Diterima \\
\hline
\end{tabular}

Sumber : Data Diolah 2019

Dari tabel 5 di atas hasil regresi linier berganda dapat dilihat bahwa nilai $t_{\text {hitung }}$ dari harga salak pondok adalah sebesar 7,776 dengan nilai signifikannya adalah 0,000 , sementara nilai $t_{\text {tabel }}$ dengan $(\mathrm{df})=\mathrm{n}-\mathrm{k}(100-4=96)$ pada $\alpha=$ 0,01 diperoleh nilai sebesar 2,62 artinya kecil dari derajat kesalahan sebesar $1 \% \quad(0,01)$. Maka keputusannya menolak $H_{0}$ dan menerima $H_{1}$, yang berarti secara parsial harga salak pondok 
berpengaruh positif terhadap permintaan di Kota Lhokseumawe.

Selanjutnya nilai $t_{\text {hitungdari harga salak medan }}$ adalah sebesar -3,407 dengan nilai signifikannya adalah 0,0010, sedangkan nilai $t_{\text {tabel }}$ sebesar 2,62 artinya lebih kecil dari derajat kesalahan sebesar $1 \%(0,01)$. Maka keputusannya menolak $H_{0}$ dan menerima $\mathrm{H}_{2}$, yang berarti secara parsial harga salak medan berpengaruh secara negatif terhadap permintaan di Kota Lhokseumawe.

Berikutnya variabel nilai $t_{\text {hitung }}$ dari tingkat Pendapatan adalah sebesar 7,663 dengan nilai signifikannya adalah 0,0000 , sedangkan nilai $t_{\text {tabel }}$ sebesar 2,62 artinya lebih kecil dari derajat kesalahan sebesar $1 \%(0,01)$. Maka keputusannya menolak $H_{0}$ dan menerima $H_{3}$, yang berarti secara parsial tingkat pendapatan berpengaruh terhadap permintaan di Kota Lhokseumawe.

\section{Pembuktian Secara Simultan (Uji F)}

Uji F dilakukan untuk mengetahui apakah variabel-variabel independen secara keseluruhan secara statistik mempengaruhi variabel dependen. Apabila nilai $F_{\text {hitung }}$ lebih besar dari nilai $F_{\text {tabel }}$ maka variabel-variabel independen secara keseluruhan berpangaruh terhadap variabel dependen, dan sebaliknya apabila nilai $F_{\text {hitung }}$ lebih kecil dari nilai $F_{\text {tabel }}$ maka variabel-variabel independen secara keseluruhan tidak berpangaruh terhadap variabel dependen. Hasil pengujian secara simultan dapat dilihat pada tabel di bawah ini :

\section{Tebel 6}

Hasil Uji f

\begin{tabular}{|c|c|c|l|l|}
\hline F-Statistik & F-tabel & Prob & Keterangan & $\begin{array}{l}\text { Hipotesi } \\
\mathrm{s}\end{array}$ \\
\hline 38.81902 & 3,99 & 0.000 & Signifikan & Diterima \\
\hline
\end{tabular}

Sumber : Data Diolah 2019

Dapat diketahui bahwa nilai $F_{\text {hitung }}$ sebesar 38,819 dengan nilai signifikan sebesar 0,000 pada taraf kepercayaan $95 \%$. Sedangkan $F_{\text {tabel }}$ diperoleh nilai sebesar 3,99 pada $\alpha=0,01$. Dengan demikian $F_{\text {hitung }}>F_{\text {tabel }}$ yaitu 17.65> 3,99 dan nilai signifikan sebesar $0,000<0,01$. Dari hasil uji $\mathrm{F}$ ini berarti $H_{a}$ diterima atau menolak $H_{0}$, dengan demikian harga salak pondok, harga salak medan dan tingkat pendapatan secara bersama-sama berpengaruh positif terhadap permintaan di Kota Lhokseumawe.

\section{Uji Koefisien Korelasi (R)}

Koefisien korelasi merupakan besarnya hubungan antara variabel yang satu dengan variable lainnya dinyatakan dengan koefisien korelasi. Nilai koefisien korelasi adalah $R=$ $\sqrt{R^{2}}=\sqrt{0,5340}=0,7307 \quad(73,07 \%)$ yang menunjukkan bahwa hubungan antara variabel harga salak pondok, harga salak medan dan tingkat pendapatan terhadap permintaan memiliki hubungan yang kuat secara positif karena nilai korelasi 0, 7307 hampir mendekati positif satu $(+1)$.

\section{Uji Koefisien Determinasi $\left(\mathbf{R}^{\mathbf{2}}\right)$}

Dalam perhitungan statistik nilai $\mathrm{R}^{2}$ yang digunakan adalah adjusted R-squared.

Adjusted R-squared $=0.534023$

Koefisien determinasi pada regresi linier sering diartikan sebagai seberapa besar pengaruh semua variabel bebas dalam menjelaskan varians dari variabel terikatnya. Secara sederhana koefisien determinasi dihitung dengan mengkuadratkan koefisien korelasi (R).

Maka nilai koefisien determinasi $\left(R^{2}\right)$ sebesar 0,5340 yang artinya bahwa ada kaitan antara variabel bebas dan variabel terikat, perubahan yang terjadi pada variabel terikat dapat dijelaskan oleh variabel bebas sebesar 0,5340 $(53,40 \%)$, sedangkan yang dipengaruhi oleh variabel lain diluar model ini adalah sebesar 1$0,5340=0,466(46,6 \%)$.

\section{Pembahasan}

\section{Pengaruh Harga Salak Pondoh Terhadap Permintaan}

Berdasarkan hasil analisis data ditemukan bahwa variable harga salak pondok (x1) berpengaruh secara positif terhadap permintaan (Y) dengan nilai signifikan $=1 \%$. Hal ini bermakna bahwa semakin tinggi harga salak pondok (x1), maka semakin tinggi pula 
permintaan terhadap salak pondok di Kota Lhokseumawe.

Hasil penelitian ini sejalan dengan penelitian yang dilakukan oleh Ibnu Muchtar Rosyidi (2016) di Kabupaten Sukoharjo, Harga Semangka sebagai Variabel X1 berpengaruh positif terhadap permintaan semangka di Kabupaten Sukoharjo dengan nilai 0,318. Ini menunjukkan bahwa di Kabupaten Sukoharjo buah semangka bersifat barang normal karena nilai elastisitas bernilai positif dengan saran sebaiknya petani semangka lebioh cermat dalam merencanakan penanaman semangka, jumlah yang ditanam sebaiknya disesuaikan dengan permintaan disaat waktu panen. Selain itu, saran bagi pedagang sebaiknya lebih meningkatkan promosi untuk meningkatkan penjualan buah.

Hasil penelitian sesuai dengan penelitian yang pernah dilakukan oleh Ari Medika (2016) di Kota Denpasar menyatakan bahwa penelitian ini pada harga buah salak bali berpengaruh terhadap permintaan. Ini menunjukkan bahwa bahwa elatisitas harga atas permintaan buah salak bali adalah elastis, elastisitas silang menunjukkan buah jeruk dan buah apel sebagai barang komplementer dari buah salak Bali dan buah manga subtitusi dari buah salak Bali.

\section{Pengaruh Harga Salak Medan Terhadap Permintaan}

Berdasarkan hasil analisis data ditemukan bahwa variabel harga salak medan (x2) berpengaruh terhadap variabel permintaan $(\mathrm{Y})$ dan signifikan sebesar $=1 \%$. Hal ini bermakna bahwa jika harga salak medan () meningkat $\mathrm{Rp} 1$, makaakan menurunkan permintaan salak medan di Kota Lhokseumawe. Hal ini bermakna bahwa ketika harga slak medan meningkat konsumen akan mengeluhkan dan akan beralih atau melakukan subtitusi dengan buah salak lain yang dianggap sama atau serupa dengan buah salak medan.

Hasil penelitian ini sejalan dengan penelitian yang pernah dilakukan oleh Ibnu Muchtar Rosyidi (2016) di Kabupaten Sukoharjo bahwaapabila harga semangka sebagai salak subtitusi meningkat maka konsumen akan melakukan subtitusi dengan buah yang lain. Permintaan buah apel dan buah pisang sebagai buah komplementer karena elastisitas permintaannya bersilang negatif

\section{Pengaruh Tingkat Pendapatan Terhadap Permintaan}

Berdasarkan hasil analisis data ditemukan bahwa variabel tingkat pendapatan (x3) berpengaruh terhadap variable perminaan $(\mathrm{Y})$ dan signifikan pada $=1 \%$. Hal ini bermakna bahwa, tingkat pendapatan (x3) meningkat $\mathrm{Rp} 1$ maka akan meningkatkan permintaan di Kota Lhokseumawe. Hal ini dapat disimpulkan bahwa pendapatan seseorang akan menentukan kebutuhan konsumsi yang diinginkan, semakin tinggi pendapatan seseorang akan mampu memenuhi kebutuhan konsumsi yang tinggi pula sesuai dengan kemauannya.

Hasil penelitian ini sejalan dengan penelitian yang pernah dilakukan oleh Ari Medika (2016) bahwa semakin tinggi pendapatan rumah tangga, maka semakin tinggi pula permintaan untuk pola konsumsi terhadap buah salak bali di Kota Denpasar.

\section{KESIMPULAN DAN SARAN \\ Kesimpulan}

Berdasarkan hasil penelitian yang dilakukan penulis melalui kuisioner dan hasil olahan data dengan regresi linier berganda maka dapat diambil beberapa kesimpulan sebagai berikut:

1. Hasil yang ditemukan variabel harga salak pondok berpengaruh secara positif terhadap permintaan. Adanya pengaruh ini menunjukkan bahwa seiring dengan terjadinya peningkatan harga salak pondok, maka permintaan juga akan meningkat.

2. Variabel harga salak medan berpengaruh secara negatif terhadap permintaan artinya semakin tinggi harga salak medan, maka permintaan akan terjadi penurunan.

3. Variabel tingkat pendapatan berpengaruh secara positif terhadap permintaan. Adanya pengaruh ini menunjukkan bahwa seiring dengan terjadinya peningkatan pendapatan, maka permintaan juga akan meningkat.

4. Secara bersama-sama variabel harga salak pondok, harga salak medan dan tingkat pendapatan, berpengaruh positif terhadap 
permintaan, dan besarnya pengaruh harga salak pondok, harga salak medan dan tingkat pendapatan terhadap permintaan adalah sebesar $53,40 \%$ dan sisanya sebesar (1$53,40 \%)=46,6 \%$ dapat dijelaskan diluar model penelitian ini.

\section{Saran}

Adapun beberapa saran-saran yang diharapkan penulis dalam penelitian ini adalah sebagai berikut:

1. Hasil penelitian menunjukkan semua variabel yang diteliti berpengaruh terhadap permintaan, tingginya harga salak pondok berpengaruh terhadap permintaan namun berpengaruh dalam model positif, terkadang masyarakat tidak hanya melihat dari tingkat harga namun kebanyakan masyarakat melihat dari tingkat rasa yang diciptakan dari salak pondok tersebut. Diharapkan kepada petani dan pedagang agar dapat memberi stock yang relatif besar terhadap penjualan salak pondok.

2. Mengintensikan kembali bahwa buah salak pondok memiliki kandungan yang baik bagi kesehatan masyarakat, berbagai macam kandungan nutrisi yang dimiliki oleh salak pondok. Jumlah sajian tersebut diperoleh dari 100 gram buah salak pondok dengan jumlah bagian buah yang dapat dikonsumsi adalah sebanyak $59 \%$.

3. Diharapkan kepada Pemerintah setempat agar mensosialisasikan pentinganya mengkonsumsi buah-buahan termasuk buah salak pondok, dengan menjelaskan manfaat yang diberikan dari buah tersebut seperti menjaga kesehatan mata, obat diare yang alami, obat diet yang alami, meningkatkan sistem kekebalan tubuh, dan menyehatkan kulit. Perlu adanya penelitian lanjutan, sehingga diperoleh temuan yang lebih bervariasi dan lebih baik dalam menjelaskan permintaan dengan metode penelitian yang berbeda.

\section{DAFTAR PUSTAKA}

Bilas R.A.2005. Teori Ekonomi Mikro. Erlangga. Jakarta.

Hanafiah dan Saefuddin. 2015. Kawasan Pengembangan Salak. Direktorat Budidaya Tanaman Buah. Direktorat Jenderal Holtikultural. Departemen Pertanian.

Slamet, Saksono. 2002. Manajemen Sumber Daya. Jakarta. Indeks.

Soetomo. 2010. Potensi Ekstrak Kulit dan Daging Buah Salak Sebagai Antidianetes. Bogor. Program Studi Biokimia Fakultas MIPA.

Suroto. 2000. Apresiasi Sastra Indonesia. Jakarta: Erlangga.

Sukirno, S. 2002. Hukum Permintaan. Raja Grafindo Persada. Jakarta.

Virgantari, dkk. 2011. Analisis Permintaan Ikan di Indonesia: Pendekatan Model Quadratic Almost Ideal Demand System (QUAIDS). Jurnal Sosek KP. Vol. 6(2).

Winardi. 2014. Marketing Dan Perilaku Konsumen CV. Mandar Maju. Bandung 